\title{
Inter Nagari Conflict (Case Study: Conflict of Nagari Bidar Alam and Lubuk Malako in Sangir Jujuan Subdistrict, South Solok Regency)
}

\author{
Nofri Alpules ${ }^{1, *}$ \\ ${ }^{1}$ Department of Sociological Education, Postgraduate Program, Universitas Negeri Padang,Padang, Indonesia \\ *Email: alpulesnofri@gmail.com
}

\begin{abstract}
The conflicts between Bidar Alam and Lubuk Malako village is happened every year, problems that occur in the southern Solok Regency, namely between Nagari Lubuk Malako and Bidar Alam, where the conflict occurred from around 1998 to 2016, and the it has not been resolved, This study uses the theory of conflict by George simmel. One of the basic forms of social interaction according to Simmel is social conflict. Each individual, group and also the community certainly has antagonistic potential with individuals, groups and also other communities. According to Simmel, it cannot be separated from the surrounding community. This study uses a qualitative approach to the type of instrumental case study. The informant selection technique was purposive sampling technique. Data collection is done by observation, documentation and in-depth interviews, researchers triangulated data. The analysis in this study used an interactive model developed by Mathew Miles and Hubermans. The results of this study are the Causes of Conflict of Nagari Bidar Alam with Lubuk Malako are the distribution of power of the location of car agents, locations of high schools and junior high schools in Nagari Bidar Alam, courage in their own area, lack of interaction between bidar alam and lubuk malako, mutual booing regional languages, and old revenge. The positive impact of the conflict between Nagari Bidar Alam and Lubuk Malako, namely: the unity of each nagari is getting stronger, the birth of new consensus (agreement) in the community, and opening the public's insight about the ongoing conflict. Then the researchers also found four negative impacts of the conflict between Nagari Bidar Alam and Lubuk Malako, namely: the fall of casualties and injuries, property damage, the breakdown of relations between the two conflicting nagari, and the emergence of acts of community anarchism. Nagari Bidar Alam and Nagari conflict resolution Lubuk Malako, namely: consultation of nagari guardians and ninik mamak, mediation by the police, nagari government and district government, government policy initiatives in compensating all losses of both parties due to conflict, building police posts at the border of narari bidar nature and nagari lubuk malako, and every seed that emerges will be immediately handed over to the police.
\end{abstract}

Keywords: conflict, community, impact of conflict

\section{INTRODUCTION}

The Indonesian nation is known as a plural nation, plural society in terms of ethnicity, religion, culture and many others. The pluralism of the Indonesian people caused conflicts between religions and religions as well as between other groups. Internal conflicts that occur in Indonesia are conflicts between social groups in society that take ethnic and religious origins and conflicts between groups Klinken[1] \& Masyrullahushomad[2].

Conflict is a social phenomenon that always exists in a life together. Actually conflict is not difficult to eliminate, but conflict needs to be controlled will always be in the community, this is because in that community there is authority. The intention was contained regarding the replacement of parties to the authority so that on the other party authority would be reduced. Putman and Pool state that there are differences of interests between groups one with another group, who have opposite goals and with others as bullies that have the potential to oppose their goals [3].

Depressed conflicts can cause a breakup, and if the emotional heightens, the breakup can suddenly explode. in accordance with observations on 14-16 November 2016, that conflicts that occur between Bidar Alam and Lubuk Malako often occur every year, it is in southern Solok Regency, namely between Nagari Lubuk Malako and Bidar Alam, where the conflict occurred from the past around in 1998, which was triggered by a group of young men, car agents (brokers), then occurred again in 2000 caused by a fight between high school children involving the two villages, then in 2003 resurfaced conflict between residents which caused injuries to the community involved, then in 2004 it happened again, in 2006 the conflict occurred again which was triggered by high 
school students, then in 2009 the conflict occurred again which was triggered by the youths who were doing wild races, and there was no resolution.

While in 2010 there was a conflict the day after the Eid alFitr, based on data collected, the conflict that occurred between Nagari Bidar Alam and Lubuk Malako in Sangir Jujuan Subdistrict, South Solok Regency, the conflict caused the death of one person caused by firearms and injuries - injured dozens of people from both Nagari. 16 residents' houses and three motorbike units were set on fire in Nagari Lubuk Malako in 2010 around 3:00 pm West Indonesia Time, and in July 2016 involving two Nagari youths, but this was quickly resolved by the authorities namely police officers, the potential for them to occur conflict is very easy between Nagari Bidar Alam and Lagari Lubuk Malako.

Deliberation is often carried out by both parties, namely the Wali Nagari of the two Nagari in conflict, based on the results of interviews with the Mayor of Nagari Bidar Alam who took office in 1998, Mr. Khaidir, he explained that the peace process had been attended by representatives of both nagari attended by the chairman of KAN from each village, but conflicts still occur. Every conflict that occurs can have a positive or negative impact. The meeting point that did not have results in the process of resolving this conflict caused a protracted conflict to the present day to continue. Based on the problems that the researcher explained above, the researcher was interested in conducting research on village conflict (Case Study: Conflict of Nagari Bidar Alam and Lubuk Malako in Sangir Jujuan, South Solok regency)

\section{RESEARCH METHOD}

This type of research is qualitative research using the type of case study. Research data were collected through observation, interviews and documentation. The informants in this study are those who are considered to be able to provide maximum information related to conflicts between Nagari bidar Alam and lubuk malako. Data was analized by collecting data, reducing data, presenting data and drawing conclusions by triangulating data sources and methods.

\section{RESULTS AND DISCUSSION}

\subsection{Special Findings}

\subsubsection{Conflict causing factors Nagari Bidar Alam and Lubuk Malako}

Factors that cause conflict are individual differences which include differences in stance and feelings. Differences in cultural backgrounds so as to form different personalities someone will more or less be affected by the patterns of thought and establishment of the group. Differences in interests between individuals or groups, including concerning the economic, political, and social fields as well as rapid and sudden changes in values in society.

Based on the provisions in Article 5 of Law No. 7 of 2012 concerning the handling of social conflicts, the sources of conflict can be such as issues related to politics, economics, social, culture, intersections and disputes over village boundaries as well as natural resource disputes between communities and unequal distribution of natural resources within the community. Differences in cultural background form different individuals, because basically a person will be affected by the patterns of thought and establishment of his group. besides that there were many factors that led to the conflict between Bidar Alam and Lubuk Malako communities.

\subsubsection{Division of Car Agent Areas}

Power is selfishness in a group even though selfishness has opposition, it is still unable to resist due to the existence of this power. power is the power of the group, the power of the king, the power of state officials, and groups. So that it is not wrong to say that power is the ability to influence other parties according to the will that is in the holder of power. Humans apply as subjects as well as objects of power and place controlled.

\subsubsection{Location of high schools and junior high schools located in Bidar Alam}

The location of education is a factor in the trigger of conflicts that occur in Nagari Bidar Alam and South Solok, plus the location of schools located in Nagari which is a conflict, so that the community is increasingly lazy to go to school.

\subsubsection{Bagak di Kampuang Surang (Brave in $\underline{\text { Your Own Area) }}$}

This inter-village conflict was also caused by the mentality of brave in their own area, this can be seen from the behavior and actions of various elements of the community of the two villages. For example, the elements of the Nagari Bidar Alam students who lighted the students of Nagari Lubuk Malako at school, of course one of the factors was because the school was in their area

\subsubsection{Lack of Interaction Between Bidar Alam and Lubuk Malako Communities}

In civil society or social life, social conflicts often occur in opposing the same object. This is triggered by different perspectives in interpreting a problem. The different schools or ideologies adopted by each party to the dispute 
make social friction can turn into real social conflict, this conflict can be mentioned, among others, fights between citizens triggered by things that in normal life are considered simple or trivial, such as the problem of the administrative area of the village or regency that is to be divided and the bad behavior of the youth, that is, pretentious is not polite and arbitrary.

\subsubsection{Muttering Regional Languages}

Culture has its own values that must be obeyed and these values are also used as a basis in acting and behaving in daily life. Various cultural values contained in the culture are guarded and preserved through cultivation, protection carried out by the family and all levels of society. And if it ignores all the cultural values of the nation or region it is considered as a resistance and betrayal of the ancestors who have inherited it. Pride of the group and looking down on other groups often triggers conflicts such as the language of customary procedures and others.

\subsubsection{Old Revenge}

Old revenge greatly affects the recurrence of conflict in this case the parties in conflict are difficult to live a peaceful life. Conflict is a product that arises from a relationship between individuals, conflict arises because of a dispute-disputes, so as to resolve conflicts can be done by rectifying disputes that occur, hatred or resentment of the community between the villages

\subsubsection{Impact of Nagari Bidar Alam and Lubuk Malako conflicts}

\subsubsection{Positive impact}

\subsection{The Unity of Each Nagari Is Stronger}

When a conflict occurs, each group will try to strengthen the solidarity of each group member. In addition, when the competition is carried out correctly and if honesty is prioritized, there will be harmony in the group so that cohesiveness is created

\subsection{Birth of a New Consensus (Agreement) in the Community}

Conflict in any form sometimes has a positive side, like the conflict between Bidar Alam and Lubuk Malako also has a positive side, namely the birth of a new agreement between the two nagari which is formulated together to prevent conflict in the future. Whereas before this conflict, between the Bidar Alam and Lubuk Malako communities, if a dispute occurred, it was always resolved in the wrong way, for example fighting, disputes, mutual ridicule, and so forth. Then this positive impact can be seen on both villages in an effort to realize the alignment of both villages.

\subsection{Opening up People's Insights About the Conflict That Is Happening}

The conflict that occurred between nagari Bidar Alam and Lubuk Malako indirectly opened the public's insight into the conflicts that had occurred in their village. Of course not all members of the community get the right information about what actually caused the conflict between the two village, or what the conflict actually happened. During this time the community only hears rumors internally in their village about the conflict, but after various efforts made by various parties, this conflict has shed some light on its resolution

\subsubsection{Negative impact}

\subsection{The Fall of Soul and Injury Victims}

Social conflict is often followed by the actions of group members from each camp to act on violence. Damage to residences, public facilities, and so on, is concrete evidence that social conflict has a negative impact on the ownership of property from each group. In addition, the frequent violence during social conflicts also caused the death of 1 person from Lubuk Malako and dozens of people were injured during the conflict that occurred in 2010. Injured victims from each village, or even the victim died from one of the or each village. Unfortunately, even the loss of life from one of the groups can be used as an excuse to carry out more brutal attacks, leading to greater conflict and greater losses as well.

\subsection{Damage to Property}

Often the location of this conflict called the war between villages occurs in the Nagari Lubuk Malako area even though at first this war began at the second border of the nagari yaitunya on a straight road along a rice field of about 100 meters which separates the two nagari, but usually extends to the three Nagari intersections The Malako Lubuk. After this war the victims are usually the victims not only of human beings but also of the surrounding infrastructure such as destroyed homes and roads filled with stones. 
involving the two young men of Nagari Bidar Alam and Lubuk Malako, which initially occurred in 1998, the settlement of the conflict which had been carried out by deliberation.

A conflict between groups inevitably, even though they have made peace, will certainly leave hatred to some individuals in certain groups. Of course, the rift between the conflicting groups is something that can not be avoided and can be the cause of acts of abuse of authority.

\subsection{Emergence of Community Anarchism}

Actions

The disputes between the two village had an impact on many things in the relations of the two villages communities, anarchism which often happened as if the youth of each village met elsewhere then they would gang together, and even if the Bidar Alam residents crossed Nagari Lubuk Malako would be thrown stone and vice versa. Not infrequently because trivial matters of the conflict extend into conflicts between the village. For example, when trading in one of the two nagari markets, then there was a young man who was touched by a young man from Lubuk Malako or Bidar Alam, so it was easy to end with a war between the two village communities.

\subsubsection{Conflict Resolution Nagari Bidar Alam and Nagari Lubuk Malako}

According to Maswadi[4] conflict resolution is the efforts made to resolve or eliminate conflicts by seeking agreement between the parties involved in the conflict. Conflict resolution is needed to prevent: (1) the depth of the conflict, which means that the differences between the conflicting parties are sharpened; (2) the more widespread conflict, which means the increasing number of participants of each conflicting party which results in a deeper and more widespread conflict, even leading to community disintegration that can produce two separate and hostile community groups

\subsection{Wali Nagari Deliberation and Ninik Mamak}

In resolving conflicts must pay attention to laws, regulations, or regulations, but conflict resolution is carried out by debating the rules of the game in the laws, regulations or regulations. This can be done by involving formal institutions, such as courts, arbitration institutions and the like. The point is, laws, regulations, regulations, become the reference and are highly considered, further resolving conflicts is by consultation, negotiation, or whatever they are called, which results in agreements between all parties. The agreement can take the form of an agreement, and at a higher level such as a conflict

\subsection{Mediation by the Police, Nagari Government and District Government}

Often the failure of resolving problems with deliberations from year to year due to conflict occurs again the next attempt is to mediate, the mediation process is carried out by both parties in this case the police and the government are the mediators

\subsection{Government Initiative in Replacing All Losses between Both Parties Due to Conflict}

The direct involvement of local governments as mediators in resolving conflicts between Nagari Bidar Alam and Nagari Lubuk Malako shows that the conflict is very serious and requires adequate conflict resolution strategies to resolve the conflict. In this case in order to defuse the situation and reach an agreement malaka in the end the government pays all losses of property due to the conflict with a record that the conflict must not be repeated. If the conflict repeats, the government will not re-launch similar initiatives because it is feared that the resolution will become an opium for the community to trigger aftershocks

\subsection{Building a Police Station at the Border of Nagari Bidar Alam and Nagari Lubuk Malako}

This conflict between Nagari Bidar Alam and Lubuk Malako is very easy to emerge due to small things. When the conflict has occurred it will be very difficult to stop it because of course the loss will be suffered by both parties. To prevent this, the preventive action of the police was to build a guard post by the police stationed at the location of the conflict, right at the junction of the intersection of Nagari Lubuk Malako. So if something happens that leads to conflict between the two nagari, the guarding police will be able to carry out fast response so that there is no recurrence of a much larger conflict as happened before.

\subsection{Every Conflict Seedling that arises will be} immediately handed over to the Police Department

The conflict that occurred between Nagari Bidar Alam and Nagari Lubuk Malako was very easy to happen by small things. This seems to occur because there are no penalties for provocateurs or parties who cause conflict, and also for people involved in the conflict. In disguised youths who are the cause of the conflict even have their own pride 
because they are supported by people in the same village even though because of his own behavior, but seeing the condition as a result of the ninik mamak consultation, ulama scholars, smart cadiak, the nagari government and the local government and the police, it was decided that every trigger of a conflict caused by any party and whoever is a person will then be handed over directly to the realm of law which in this case will be processed by the police

\section{DISCUSSION}

This study uses conflict theory by George Simmel. Simmel in Ahmadin[5] maintains his opinion that sociology works to perfect and develop forms or concepts of sociology in which the contents of the empirical world can be placed. An explanation of Simmel's conflict theory is as follows: Simmel views the dispute as a symptom that is impossible to avoid in society. The social structure is seen as a phenomenon that includes a variety of associative and dissociative processes that cannot be separated, but can be distinguished in the analysis. According to Simmel conflict is subject to change. Coser developed the proposition and broadened Simmel's concept in describing the conditions in which conflict positively helps social structure and if it occurs negatively it will weaken the framework of society [6].

One of the basic forms of social interaction according to Simmel is social conflict. Each individual, group and also the community certainly has antagonistic potential with individuals, groups and also other communities according to Simmel cannot be separated from the surrounding community. Individual behavior is also influenced by their social environment. Instead society refers to patterns of mutual interaction between individuals. Simmel further analyzed social interactions at the micro level that emphasized interpersonal social reality [7].

\subsection{Causes of Nagari Bidar Alam Conflict with Nagari Lubuk Malako}

Every conflict that occurs in the community certainly cannot be separated from the various factors that trigger the conflict to occur. Is it because of individual factors or because of group factors, then it might also be caused by economic factors, power, competition, and so on. Factors that cause conflict between Nagari Bidar Alam and Nagari Lubuk Malako, as follows: Distribution of Power, School Location, Bagak in Kampuang Surang (Brave in Their Own Area), Lack of Interaction between Communities, Mutual Abuse of Regional Languages, and Old Revenge In this case the conflict that occurred between Nagari Bidar Alam and Nagari Lubuk Malako occurred because it was caused by the factor of power distribution of the location of the car agent which was related to the difference in interests between the car dealer business entities between the two villages. Where in this case the young Nagari Bidar Alam is considered inappropriate to control the location of car dealership in the Nagari Lubuk Malako area even though in Nagari the young nagari also have the same business. Nagari Youth Lubuk Malako wants that Nagari Bidar Alam youths no longer control car dealerships in their area. This mismatch of interests has led to widespread disputes between conflicts between the nagari.

At that time, if they wanted to go to public high school, Nagari Lubuk Malako's children would not want to go to Nagari Bidar Alam because the only public high school near Nagari Lubuk Malako was in Nagari Bidar Alam. Likewise, the existence of a junior high school in Bidar Alam. Factors in the location of high schools and junior high schools in Bidar Alam, where some students from Bidar Alam feel above the wind or other terms Bagak in Kampuang Surang surang (brave in their own village), these feelings which then become a trigger for the occurrence of bullying from students from other regions, one of which is students from Nagari Lubuk Malako.

Simmel's conflict theory views conflict as a symptom that cannot be avoided in society. The social structure is seen as a phenomenon that includes a variety of associative and dissociative processes that cannot be separated, but can be distinguished in the analysis. Then according to Simmel, conflict is subject to change. Coser developed the proposition and broadened Simmel's concept in describing the conditions in which conflict positively helps social structure and if it occurs negatively it will weaken the framework of society.

This inter-village conflict was also caused by the mentality of the Bagak community in Kampuang Surang (courage in their own area), this can be seen from the behavior and actions of various elements of the community of the two villages. For example, elements of Nagari Bidar Alam students who are bullying Nagari Lubuk Malako students at school, on the other hand Nagari Lubuk Malako youths also often intimidate Nagari Bidar Alam youths if they pass by in their area or go to their nagari at org events, dating, etc. so.

The minimal factor of interaction between the villages raises the boundary of interaction between the two villages so that community members consider their villages to be different from other villages, and then bring up elements of competition which unfortunately are negative in nature leading to the desire to defeat, bringing down the other village which is then called conflict between the villages. This is also due to the limited activities that can be carried out jointly between the two nagari communities, of course these conditions will cause the community not to know each other and not to create social integration.

Culture has its own values that must be obeyed and these values are also used as a basis in acting and behaving in daily life. Various cultural values contained in the culture are guarded and preserved through cultivation, protection carried out by the family and all levels of society. And if it ignores all the cultural values of the nation or region it is considered as a resistance and betrayal of the ancestors who have inherited it. Pride of the group and looking down 
on other groups often triggers conflicts such as the language of customary procedures and others

Old revenge is a very dominant thing that causes conflict to occur again from year to year, hatred and resentment has been embedded in the people of both village. This old grudge has never stopped for one generation because it is continually instilled in the next generation unconsciously, where in each region the community often reports on discussing, vilifying other village communities, then that knowledge is indirectly internalized into the next generation.

Simmel's conflict theory views conflict as a symptom that cannot be avoided in society. The social structure is seen as a phenomenon that includes a variety of associative and dissociative processes that cannot be separated, but can be distinguished in the analysis. Then according to Simmel, conflict is subject to change. Coser developed the proposition and broadened Simmel's concept in describing the conditions in which conflict positively helps social structure and if it occurs negatively it will weaken the framework of society.

According to researchers the role of the regional government and village government including community leaders is very important in efforts to unite or reconcile between Nagari Bidar Alam and Nagari Lubuk Malako. In this case it can go through various aspects, namely; first, education. The government must encourage the children to continue their education to the highest possible extent and the government must also provide the means and means of infrastructure in an effort to realize this. Then the government must also intensify socialization activities on the importance of cooperation and unity. Second, create a joint activity program. Through a joint program of activities, the two village communities will get to know each other, foster a feeling of togetherness so that the old revenge will gradually diminish or be forgotten. Third, make a policy or rule. The government must immediately make a policy or rule relating to the person who raises the seed-bit conflict between the two villages and resolves according to the law by the related parties, for example police.

\subsection{Impact of Nagari Bidar Alam and Lubuk Malako Conflicts}

Social conflict basically does have two sides of impact on society. It can have a positive or negative impact even though human nature always tries to avoid conflict because it is identical to its positive presence for the community, namely: Unity of the village is getting stronger, Birth of a new Consensus (Agreement) in the community, opening public awareness about the conflict while the negative impacts such as , The loss of lives, property damage, the breakdown of relations between the two villages, and the emergence of acts of community anarchism.

In the reality of this research, some of the impacts of the conflict indicate a positive affiliation with the structure of society. Where the dispute that took place between the people of Nagari Lubuk Malako and the people of Nagari Bidar Alam gave rise to a high sense of solidarity with each member of the Nagari community, even eliminating internal disputes that occurred in the previous community even though it was temporary but would slightly reduce internal tensions structurally.

This conflict also brought changes to the relations between the two nagari which had previously been very difficult to control, after the conflict culminated, with the involvement of various elements of society from both the nagari and the parties involved, the two nagari finally had a commitment to peace through a peace statement. This conflict between Bidar Alam and Lubuk Malako makes it possible to readjust norms and values, as well as social relations within the group according to individual or group needs. The occurrence of conflict can foster awareness in the community of social norms and values, and social relations about the need to apply a number of rules that tend to lead to a better direction.

According to researchers, a conflict that has been going on for a long time is indeed not easy to solve thoroughly. It may also be necessary at a certain time that the conflict will escalate so that there is a bright spot from the resolution of the conflict. Then it will also attract the attention of the government and related parties who so far have not paid too much attention to resolving conflicts that occur in the community. So that after this conflict culminated, there were new agreements mediated by various parties to reduce and resolve the conflict.

On the other hand I also have confidence that conflicts do not always have to be resolved after the conflict peaks or uses repressive or curative measures, but it is hoped that the relevant parties will seek more preventive or preventive actions starting from the emergence of conflict bits, the relevant government has played an active role in resolving the conflict.

According to the researchers, from the beginning the two nagari communities must have been mediated involving the nagari government and community leaders by providing truthful and complete and objective information about what the conflicting process between the two nagari has actually been like. Old people must be given positive understanding so that parents' education is also positive for young people. Or if the elderly still do not want to leave their old grudges, then education of young people should also be able to reduce and prevent conflicts on an ongoing basis.

In a conflict of this magnitude until there was a war between the two nagari communities and using modern weapons such as air guns, gobok, samurai, and others as well as traditional weapons such as sickles, machetes, stones, chains, etc., the death toll is not impossible happened, it was a risk that actually had to be understood by both nagari communities so they should think again before the war occurred. However, in reality the two communities instead demanded mutual justice, mutual feelings of being victims, this kind of mindset which then did not provide a solution to the conflict. 
The reality of this research shows that the conflict situation has weakened the structure of society as a whole. The mindset of erroneous conflict in which the community prioritizes its egocentricity has brought greater losses to the structure where the possibility of carrying out associative processes becomes smaller and conflicts occur continuously.

Damaged infrastructure was caused by the war between the two nagari. People with uncontrolled rage destroy whatever they encounter in order to release all their emotions and anger, they no longer care about the losses incurred. When the war broke out there was no more mercy on the enemy, so that the houses, stalls, and all the facilities they found they destroyed without them thinking about how the property owner.

Simmel's conflict theory views conflict as a symptom that cannot be avoided in society. The social structure is seen as a phenomenon that includes a variety of associative and dissociative processes that cannot be separated, but can be distinguished in the analysis. Then according to Simmel, conflict is subject to change. Coser developed the proposition and broadened Simmel's concept in describing the conditions in which conflict positively favors social structure and when it occurs negatively weakens the framework of society, demonstrating that negative conflict conditions have weakened the framework of society which further makes society no longer rational and prioritize emotions in response to the conflict between the two nagari. To release all the anger, the war between nagari is very difficult to avoid so that in the process there is damage to the assets of the opposing party, the community destroys any infrastructure encountered in the area of the opposing party.

According to the researcher there must be preventive action before the wider conflict occurs, the related parties and the public must be responsive and take preventive actions so that property damage is not carried out as happened during the war between the two nagari. A conflict between groups inevitably, even though they have reconciled, will certainly leave hatred to some individuals in certain groups. Of course, the breakdown of relations between conflicting groups is something that is inevitable and can even extend to larger conflicts such as the internagari war that had previously occurred. Even though not all members of the community were at war because of the conflicts of the two nagari, but indeed each member of the two nagari communities had limited integration and could unite in interacting with the community.

The reality of research shows that anarchism acts are very easy to occur between the two nagari even though without fundamental problems, this may only be caused by the inculcation of hate values in the members of the two nagari communities. Sometimes just passing through the inter-nagari village would be very easy for conflicts to occur, for example because it was thrown at stones, cheered on, driven out of the nagari. The point is that community members consider inter-nagari as opposing parties that must be opposed and eliminated, these anarchism actions can be mitigated by involving mediation from related parties such as the police who set up guard posts at the border between the two nagari. It seems to be very effective in reducing acts of anarchism between members of the two nagari communities, although it is not able to eliminate hostilities as a whole. In my opinion, gradually with the increase in the education level of the two nagari communities, the condition of the relationship between the two nagari will be more conducive because an educated HR will certainly be more rational in thinking and more constructive.

\subsection{Conflict Resolution Nagari Bidar Alam and Nagari Lubuk Malako}

According to Maswadi[4] conflict resolution is the efforts made to resolve or eliminate conflicts by seeking agreement between the parties involved in the conflict. Conflict resolution is needed to prevent: (1) the depth of the conflict, which means that the differences between the conflicting parties are sharpened; (2) the more widespread conflict, which means the increasing number of participants of each conflicting party resulting in a deeper and more widespread conflict, even leading to community disintegration that can produce two separate and hostile community groups. There are two ways of resolving conflicts, namely: Wali Nagari Deliberation and Ninik Mamak and Mediation by the Police and District Government.

In resolving conflicts must pay attention to laws, regulations, or regulations, but conflict resolution is carried out by debating the rules of the game in the laws, regulations or regulations. This is usually done by involving formal institutions, such as courts, arbitration institutions and the like. The point is that laws, regulations, regulations, become the reference and are highly considered, and the higher resolution of conflicts is through deliberation, negotiation, or whatever they are called, which results in agreements between all parties. The agreement can take the form of an agreement, and at a higher level such as a conflict involving the two young men of Nagari Bidar Alam and Lubuk Malako, which initially occurred in 1998, the settlement of the conflict which had been carried out by deliberation.

Often the failure of solving problems with deliberation from year to year because the conflict occurs again, the next attempt is to mediate, the mediation process is carried out by both parties in this case the police and government are the mediators. During this time in resolving the conflict Nagari Bidar Alam and Lubuk Malako carried out by deliberation and consensus, but after the conflict in 2010 only mediation was held involving the police and government, in this case the government was the one who replaced all the damage caused by the conflict.

This mediation by the nagari government, regional government and the police is what is needed from the beginning to resolve conflicts between the two nagari because naturally the mediation results are more powerful and lawful, so that the elements of the two nagari who are the cause of the larger conflict will be responsible for their 
actions before the conditions it became a wider conflict. In this case the presence of the police as a mediator with legal force is very important in controlling community actions that lead to conflicts between the two villages.

Simmel's conflict theory views conflict as a symptom that cannot be avoided in society. The social structure is seen as a phenomenon that includes a variety of associative and dissociative processes that cannot be separated, but can be distinguished in the analysis. Then according to Simmel, conflict is subject to change. Coser developed the proposition and broadened Simmel's concept in describing the conditions in which conflict positively helps social structure and if it occurs negatively it will weaken the framework of society. According to Maswadi[4], conflict resolution is efforts that are made to resolve or eliminate conflicts by seeking agreement between the parties involved in the conflict.

The reality of the research shows that before the initiative of the South Solok regional government in replacing all the losses of both parties due to the conflict, the two nagari communities were still arguing not to reconcile and question various matters, even conditions tended to still heat up. However, after the initiative was taken, the two nagari communities that suffered losses were more permissive to the peace efforts mediated by the regional government, the nagari government, and the police

Although not educative in nature, the provision of compensation is still effective in reducing the anger of the community towards the opposing party, certainly with a note not to repeat the war between the nagari. As stated in the peace agreement letter between the two nagari, the laws were written for the people who became the cause of the conflict in the past. So that the initiative to compensate for the loss of society is not used as an excuse to conduct similar conflicts in the future.

This conflict between Nagari Bidar Alam and Lubuk Malako is very easy to emerge due to small things. When the conflict has occurred it will be very difficult to stop it because of course the loss will be suffered by both parties. To prevent this, the preventive action of the police was to build a guard post by the police stationed at the location of the conflict, right at the junction of the intersection of Nagari Lubuk Malako. So that if something happens that leads to a conflict between the two villages, the police who are on guard will be able to do a fast response so that the conflict is not much bigger like what happened before.

The establishment of a police post at the conflict location was very effective in preventing the subsequent conflict between the two villages. Because the presence of a police post indirectly also makes the community of both parties more careful in interacting, or raises more vigilance so that little things are no longer easy to trigger greater conflict

\section{CONCLUSION AND SUGGESTIONS}

Based on the results of the above research, the researcher draws some conclusions from this study relating to the views of the community about conflicts between Nagari
Bidar Alam and Lubuk Malako in Sangir Jujuan Subdistrict, South Solok Regency, as follows:

\subsection{Causes of Nagari Bidar Alam Conflict with Nagari Lubuk Malako}

From the findings of this study, researchers found seven causes of Nagari Bidar Alam conflict with Naguk Lubuk Malako, namely: distribution of power of location of car agents, locations of high schools and junior high schools in Nagari Bidar Alam, courage in their own area, lack of interaction between bidar alam and lubuk Malako, mutually ridiculing regional languages, and old revenge.

\subsection{Impact of Nagari Bidar Alam and Lubuk Malako Conflicts}

From the findings of this study, researchers found three positive impacts of the conflict between Nagari Bidar Alam and Lubuk Malako, namely: the unity of each nagari is stronger, the emergence of new consensus (agreement) in the community, and open society's insight about the ongoing conflict. Then the researchers also found four negative impacts of the conflict between Nagari Bidar Alam and Lubuk Malako, namely: the fall of casualties and injuries, property damage, the breakdown of relations between the two conflicting nagari, and the emergence of acts of community anarchism.

\subsection{Conflict Resolution Nagari Bidar Alam and Nagari Lubuk Malako}

From the findings of this study the researchers found five conflict resolutions of Bidar Alam and Naguk Lubuk Malako Nagari, namely: deliberation of nagari and ninik mamak guardians, mediation by the police, nagari government, and district government, government policy initiatives in replacing all losses caused by conflict, building a police post at the border of Nagari Bidar Alam and Nagag Lubuk Malako, and every seedling of conflict that arises will be immediately handed over to the police Based on the findings of this study, the researcher suggested several things as follows: 1) Researchers should further expand research on other branches of conflict studies that exist within the community and may be done with approaches other than qualitative approaches, but quantitative approaches, and mixed methods so as to produce more diverse variations of conflict study studies. 2) The local government should be more serious in preventing conflicts in the community by first identifying the seeds of the conflict before becoming a wider conflict. 3) The local community should not be indifferent and take an active role in preventing conflicts and report directly to relevant parties if potential conflicts occur in the community. 


\section{REFERENCES}

[1] G. . Klinken, Communal Violence and Democration in Indonesia: Small Town Wars.Terjemahan oleh Bernard Hidayat. Jakarta: Pustaka Obor, 2007.

[2] Masyrullahushomad, "Mengokohkan Persatuan Bangsa Pasca Konflik Bernuansa Agama di Ambon dan Poso," J. Istor., vol. 15, no. 1, pp. 85-100, 2019.

[3] S. Wijono, Psikologi Industri dan organisasi. Jakarta: Kencana Prenada Group, 2012.

[4] R. Maswadi, Konsensus Politik dan Konflik Politik: Sebuah Penjajagan Teoritis. Jakarta: Direktorat Jendral Penddidikan Tinggi Departemen Pendidikan Nasiona, 2001.

[5] Ahmadin, "Konflik Sosial antar Desa dalam Perspektif Sejarah Bima,” J. Ilm. Mandala Educ., vol. 3, no. 1, pp. 224-232, 2017.

[6] L. Coser, The Functions Of Social Conflict, Research. New York: Free Press, 1956.

[7] D. P. Jhonson, Teori Sosiologi Klasik dan Modern. Terjemahan Robert MZ Lawang. Jakarta: PT Gramedia Pustaka Utama, 1990. 